\title{
RESERVA LEGAL AMAZÔNICA
}

\author{
IVES GANDRA DA SILVA MARTINS*
}

Pretendo, neste bre ve artigo, tecer algumas considerações sobre a Reserva Legal Amazônica.

Principio com a dicção do artigo 225, "caput" da Constituição Federal e com enunciação constante do seu $\$ 1^{\circ}$, antes da enumeração dos mecanismos e políticas para assegurar a efetividade do direito ao meio ambiente.

Está o "caput" do referido artigo assim redigido:

"Art. 225 Todos têm direito ao meio-ambiente ecologicamente equilibrado, bem de uso comum do povo e essencial à sadia qualidade de vida. impondo-se ao Poder Público e à coletividade o dever de defendê-lo e preservá-lo para as presentes e futuras gerações"!

o que vale dizer, escandindo o conteúdo da referida norma, que:

I Ao comentar o "caput" do artigo 225 da C.F. já entendia que a preservação implica política compensatória aos prejudicados, inclusive em nível internacional. Disse: "Os países europeus, que não souberam preservar sua ecologia - as florestas quase que inexistem na Europa - e que são, ao lado dos americanos, os grandes poluidores do meio ambiente, querem conservar o Brasil como "pulmões do mundo", enquanto eles próprios se transformaram na "latrina do globo". À evidência, tal custo da preservação, em benefício do planeta. de bens sujeitos exclusivamente à soberania das leis brasileiras deveria ser suportado exclusivamente pelos países mais poluidores do universo.

Cabe ao Poder Público. em primeiro lugar. a preservaçũo do meio ambiente para as gerações futuras e presentes. função esta que transcende planejamentos imediatos. que se esgotam em si mesmos, sem exigir projetos de preservação a longo prazo" "Comentários à Constituição do Brasil, $8^{\circ}$ vol., Ed. Suraiva, $2^{4}$. ed., 2000, p. 962).

* Professor Emérito da Universidade Mackenzie, em cuja Faculdade de Direito foi Titular de Direito Econômico e de Direito Constitucional e Presidente do Centro de Extensĩo Universitária. 
o que vale dizer, escandindo o conteúdo da referida norma, que:

a) todos têm direito ao meio ambiente ecologicamente equilibrado², não retirando de ninguém o usufruto de tal direito;

b) o meio ambiente é de uso comum do povo;

c) tal bem é essencial à qualidade de vida; e

d) deve ser preservado para as presentes e futuras gerações,

devendo ser, simultaneamente, defendido

e) pelo Poder Público; e

f) pela coletividade.

Por força da dicção constitucional, a preservação e a defesa competem ao Poder Público e à coletividade, por coletividade entendendo-se todo o povo, toda a sociedade.

A responsabilidade, entretanto, por sua preservação e defesa não pode ser atribuída, com "ônus", a alguém em particular, desonerando-se os demais, sempre e enquanto pertinirem à responsabilidade do Poder Público e da coletividade como um todo.

Em outras palavras, embora sejam de responsabilidade da coletividade e do Poder Público a defesa e a preservação do meio ambiente, o constituinte não criou qualquer discriminação, impondo ônus a determinadas pessoas da coletividade e não a outras, mas apenas considerou de responsabilidade da coletividade como um todo sua defesa e a preservação. E, neste caso, quando não onerosa a ação da coletividade.

Se tal responsabilidade, entretanto, implicar ônus econômico ou financeiro e, à evidência, não poucas vezes, implicará ônus para tornar efetiva sua preservação e defesa - sabiamente, o constituinte retirou a responsabilidade da sociedade e transferiu-a exclusivamente ao Poder Público.

É por esta razão que o $\S 1^{\circ}$ do artigo 225 principia com o discurso que se segue:

" $\$ 1^{\circ}$ Para assegurar a efetividade desse direito, 'incumbe ao Poder Público': ...." (grifos meus).

2 Manoel Gonçalves Ferreira Filho comenta a expressão, ao dizer: "A expressão " meio ambiente" é muito criticada, inclusive por ser, pleonástica. De fato, designa o "entorno' que cerca o homem, que é o mesmo que ambiente e o mesmo que meio. $O$ direito ao meio ambiente consiste no direito à existência de condições favoráveis à vida dos seres humanos no conjunto de elementos naturais e artificiais que o cercam: o direito a um meio ou ambiente sadio.

Sublinhe-se que o texto se exprime mal ao sugerir que o objeto do direito é o meio ambiente "ecologicamente equilibrado". O direito é a um meio ambiente "sadio", quér dizer, favorável a "boas" condições de saúde. Disso bem se apercebeu a Constituição portuguesa de 1976 (v. art. 66), que consagra o "direito a um ambiente de vida humano, sadio e ecologicamente equilibrado" (Comentários à Constituição Brasileira de 1988, vol. 2, Ed. Saraiva, 1999, p. 276). 
Ora, não consta do texto maior, neste ponto, a participação da coletividade, mas exclusivamente do Poder Público ${ }^{3}$.

Em outras palavras, o constituinte atribuiu a responsabilidade de defesa e preservação do meio ambiente, enquanto não onerosa essa atuação, ao Poder Público e à coletividade, atribuindo a intervenção onerosa exclusivamente ao Poder Público, e não à coletividade ou - e que seria pior - a "selecionados cidadãos" da sociedade.

Tal concepção constitucional, de rigor, foi aquela consagrada pela jurisprudência da Suprema Corte que, ao admitir - quando razoáveis, determinadas restrições o cabimento de indenização pela retirada do direito de usufruto, ao proprietário ou possuidor com justo título, em face da impossibilidade de dispor e explorar livremente seu bem.

Neste sentido, leia-se o seguinte trecho de acórdão em que foi relator o Ministro Rezek:

"RE 100.717-6-SP

O Código Florestal (Lei n. 4.771, de 1965) define como bens de interesse comum a todos os habitantes do país as florestas existentes no território nacional e as demais formas de vegetação, reconhecidas de utilidade às terras que revestem (art. 1), classificando como de preservação permanente as situadas ao longo dos rios, ou de outro qualquer curso dágua, ao redor das lagoas, lagos, nas nascentes, no topo de morros, montes, montanhas, serras etc.

Trata-se de limitação administrativa de caráter geral e interesse coletivo, fundada na função social da propriedade (Constituição, art.160, III), que não confere direito à indenização (cf. R.L. Meirelles, Dir. Adm. Brasileiro, 3a. ed., p.567 e segs.).

Essa restrição ao direito de propriedade não exclui, porém, a obrigação de indenizar o proprietário do solo, em caso de desapropriação. Como assinala o acórdão, negar a indenização representa atribuir efeito confiscatório à limitação administrativa" (grifos meus) ${ }^{4}$.

A primeira conclusão, portanto, nestas breves considerações, é que apenas ao Poder Público é atribuída a obrigação de preservação onerosa do meio ambiente, cabendo-lhe indenizar as restriçôes que impuser a bens pertencentes a elementos da coletividade que sejam atingidos pelas ações destinadas a preservar o meio-ambiente, dentro do princípio da razoabilidade. $\mathrm{E}$ a indenização decorrerá da perda de utilização

3 José Cretella Jr. esclarece: "384. Asseguramento da efetividade desse direito: A quem cabe assegurar a efetividade desse direito ao meio ambiente ecologicamente equilibrado, essencial à sadia qualidade de vida?

Ao Estado, evidentemente, mediante vários procedimentos, assinalados por expressas regras jurídicas constitucionais" (Comentários à Constituição 1988, vol. VIII, Forense Universitária, 1993. p. 4.518).

4 S.T.F., Serviço de Jurisprudência, D.J. 10/2/84, Ementário 1323-3. 
de seu bem em prol da comunidade, das gerações presentes e das futuras. É, aliás, o que, já à luz da Constituição de 1988, a Suprema Corte decidiu, em processo da relatoria do Min. José Celso de Mello, cuja longa ementa não permite qualquer dúvida a respeito:

\section{"13.06.95 - PRIMEIRA TURMA \\ RECURSO EXTRAORDINÁRIO N. I34297-8 SP \\ RELATOR: MINISTRO CELSO DE MELLO \\ RECORRENTE: ESTADO DE SÃO PAULO}

RECORRIDOS: PAULO FERREIRA RAMOS E CONNJUGE

EMENTA: RECURSO EXTRAORDINÁRIO - ESTAÇÃO ECOLÓGICA RESERVA FLORESTAL NA SERRA DO MAR - PATRIMÔNIO NACIO. NAL (CF, ART. 225, \$ 4') - LIMITAÇÃO ADMINISTRATIVA QUE AFETA O CONTEÚDO ECONÔMICO DO DIREITO DE PROPRIEDADE - DI. REITO DO PROPRIETÁRIO À INDENIZAÇÃO - DEVER ESTATAL DE RESSARCIR OS PREJUÍZOS DE ORDEM PATRIMONIAL SOFRIDOS PELO PARTICULAR - R.E. NÃO CONHECIDO.

- Incumbe ao Poder Público o dever constitucional de proteger a flora e de adotar as necessárias medidas que visem a coibir práticas lesivas ao equilibrio ambiental. Esse encargo, contudo, 'não exonera' o Estado da 'obrigação' de indenizar os proprietários cujos imóveis lenham a ser afetados, em sua potencialidade econômica, pelas limitaçöes impostas pela Administração Páblica.

- A proteção jurídica dispensada às coberturas vegetais que revestem as propriedades imobiliárias não impede que o 'dominus' venha a promover, dentro dos limites autorizados pelo Código Florestal, o adequado e racional aproveitamento econômico das árvores nelas existentes. A jurisprudência do Supremo Tribunal Federal e dos Tribunais em geral, tendo presente a garantia constitucional que protege o direito de propriedade. firmou-se no sentido de proclamar a plena indenizabilidade das matas e revestimentos florestais que 'recobrem áreas dominiais' privadas objeto de apossamento estatal ou sujeitas a restrições administratisas impostas pelo Poder Páblico. Precedentes.

- A circunstancia de o Estado dispor de competência para criar reservas florestais não the confere, só por si - considerando-se os principios que tutelam, em nosso sistema normativo, o direito de propriedade - a prerrogativa de subtrair-se ao pagamento de indenização compensatória' ao particular, quando a atividade pública, decorrente do exercício de atribuições em tena de direito florestal, impedir on afétal a válida exploração econômica do imóvel por seu proprietário.

- A norma inscrita no art. 225, \$4 $4^{\circ}$, da Constituição deve ser interpretada de modo harmonioso com o sistema jurídico consagrado pelo ordenamento fundamental, notadamente com a cláusula que, proclamada pelo art. $5^{\circ}$. XXII, da Carta Política, garante e assegara o direito de propriedade em 'todas' as suas projeções, inclusive aquela concernente à compensação 
financeira devida pelo Poder Público ao proprietário atingido por atos imputáveis à atividade estatal.

O preceito consubstanciado no art. $225, \S 4^{\circ}$, da Carta da República, além de 'não haver' convertido em bens públicos os imóveis particulares abrangidos pelas florestas e pelas matas nele referidas ('Mata Atlântica, Serra do Mar, Floresta Amazônica brasileira'), também não impede a utilização, 'pelos próprios particulares', dos recursos naturais existentes naquelas áreas que estejam sujeitas ao domínio privado, desde que observadas as prescrições legais e respeitadas as condições necessárias à preservação ambiental.

- A ordem constitucional dispensa tutela efetiva ao direito de propriedade ('CF/88', art. $\left.5^{\circ}, X X I I\right)$. Essa proteção outorgada pela Lei Fundamental da República estende-se, na abrangência normativa de sua incidência tutelar, ao reconhecimento, em favor do 'dominus', da 'garantia de compensação financeira', sempre que o Estado, mediante atividade que lhe seja juridicamente imputável, atingir o direito de propriedade em seu conteúdo econômico, ainda que o imóvel particular afetado pela ação do Poder Público esteja localizado em 'qualquer' das áreas referidas no art. 225. $\$ 4^{\circ}$, da Constituição. - 'Direito ao meio ambiente ecologicamente equilibrado': a consagração constitucional de um típico direito de terceira geração $(C F$, art. 225, 'cuput').

\section{ACÓRDÃO:}

Vistos, relatados e discutidos estes autos, acordam os Ministros do Supremo Tribunal Federal, em Primeira Turma, na conformidade da ata de julgamentos e das notas taquigráficas, por unanimidade de votos, em não conhecer do recurso extraordinário.

Brasília, 13 de junho de 1995. MOREIRA ALVES - PRESIDENTE, CELSO DE MELLO - RELATOR" (grifos nossos)'.

E o princípio decorre do direito de propriedade, que está entre os cinco direitos fundamentais (os cinco mais relevantes) do texto supremo, enunciados no "caput" do artigo $5^{\circ}$ da lei suprema, com as matizações dos incisos XXII, XXIII e XXIV, todos os quatro assim redigidos:

"Art. $5^{\circ}$ Todos são iguais perante a lei, sem distinção de qualquer natureza, garantindo-se aos brasileiros e aos estrangeiros residentes no pais a inviolabilidade do direito à vida, à liberdade, à igualdade, à segurança e à propriedade, nos termos seguintes: .....

XXII. é garantido o direito de propriedade:

$X X I I I$. a propriedade atenderá a sua função social;

$X X I V$. a lei estabelecerá o procedimento para desapropriação por necessi- 
dade ou utilidade pública, ou por interesse social, mediante justa e prévia indenização em dinheiro, ressalvados os casos previstos nesta Constituição" (grifos meus).

É de se lembrar que todos eles são cláusulas pétreas da lei suprema, pois colocados, em nível constitucional, como direitos e garantias individuais ${ }^{6}$.

Em outras palavras, o direito à propriedade é assegurado, na sua plenitude, com a responsabilidade de cumprir sua função social - ou seja, não ser utilizado abusivamente - lembrando-se que os direitos sociais, considerados de $2^{a}$ geração, ao tempo da conformação nos textos constitucionais anteriores assim como pela doutrina e pela jurisprudência pretérita, isto é, antes da Lei Suprema de 1988, não implicam os denominados direitos de $3^{a}$ geração. A função social, após as Constitıições de Weimar e Mexicana, implica o não uso abusivo da propriedade.

É de se lembrar episódio explicativo do que seria uso abusivo, atribuído a Santo Ives, padroeiro dos advogados e dos magistrados, pois foi magistrado e advogado, ao tempo em que era possível, na Bretanha, a cumulação de funções.

Conta-se que um pobre camponês costumava ficar nos limites da propriedade de um vizinho abastado, cuja cozinha de sua casa dava para a estrada. Ali ficava apenas para sentir o aroma das especiarias que lá se preparavam. O proprietário ingressou em juízo contra o camponês, dizendo que ele não tinha o direito de se beneficiar do aroma da preparação de alimentos que lhe pertenciam e solicitava proteção judicial para que ficasse à distância da cozinha. Considerava, portanto, o aroma ainda parte de sua propriedade e que aquele paisão o incomodava por usufruir daquilo que não lhe pertencia.

Santo Ives defendeu o "réu", tomando uma bolsa de moedas de ouro de um dos jurados e fazendo tinir as moedas nos ouvidos dos demais jurados e perguntando-lhes se pelo fato de ouvirem o tinir das moedas, eles se sentiam donos do ouro que um deles possuía. E com tal argumento mostrou que o camponês, ao sentir o aroma das especiarias emanado da cozinha de seu proprietário, não se tornava dono dos alimentos que lá eram preparados, nem seria mais ou menos alimentado, assim como os jurados não seriam mais ou menos ricos apenas por ouvirem o tinir das moedas ${ }^{7}$.

O exemplo histórico mostra em que consistia o uso abusivo e anti-social da propriedade, a que faziam menção os constituintes passados, ainda dizendo respeito aos direitos da $2^{\mathrm{a}}$ geração. Quanto aos de $3^{\mathrm{a}}$ e $4^{\mathrm{a}}$ gerações, nitidamente conformados

6 O artigo $60, \S 4^{\circ}$, inciso IV tem a seguinte dicção: " $\$ 4^{\circ}$ Não será objeto de deliberação a proposta de emenda tendente a abolir: ... IV. os direitos e garantias individuais", tendo eu o comentado: ".' Os direitos e garantias individuais conformam uma norma pétrea. Não são eles apenas os que estão no artigo $5^{\circ}$, mas, como determina o $\S 2^{\circ}$ do mesmo artigo, incluem outros que se espalham pelo texto constitucional e outros que decorrem de uma implicitude inequivoca. Trata-se, portanto, de um elenco cuja extensão não se encontra em textos constitucionais anteriores" (Comentários à Constituição do Brasil, $4^{\circ}$ vol., tomo I, Ed. Saraiva, 3a ed., 2002, p. 417).

7 Yves de Treguier, Jean Le Mappian, Editions S.O.S, Paris, 1981. 
na Carta de 88, devem, todavia, ser indenizados, conforme a jurisprudência e a doutrina, sempre que sua preservação implicar diminuição de seu usufruto pelo respectivo titular, por determinação do Poder Público.

Além, portanto. de a Constituição definir uma responsabilidade exclusiva do Poder Público para políticas ambientais onerosas, assegura o direito amplo à propriedade e ao uso não socialmente condenável, em nível de normas imodificáveis.

Neste sentido, também Miguel Reale entende ser atribuída ao Poder Público a responsabilidade exclusiva para a preservação e restauração dos ecossistemas, dizendo:

"Dir-se-á que se trata de restrição ao uso do bem florestal para atender a imperativos ecológicos, mas não há como fazer abstração da situação concreta de cada propriedade, podendo haver hipóteses de desmatamento total, ou da ordem, por exemplo de 90\% ou 95\%, isto é, sem mais possibilidade de reserva de área florestada com o mínimo de $20 \%$. como arbitrariamente impõe a lei.

Daí a conseqüência que já se quis inferir no sentido de que, se houve desmatamento que compromete a "reserva legal", caberia ao proprietário reconstituí-la a suas expensas! Onde. porém. o findamento legal para tal entendimento absurdo que afronta em cheio os principios constitucionais referidos na primeira parte do presente Parecer?

Nesse ponto, assiste razão à Consulente quando declara que se está querendo transferir ao particular o dever-que a Constituição atribui à União - de "preservar e restaurar (sic) os processos ecológicos essenciais e prover o manejo ecológico das espécies e ecossistemas" (art. 115, §1 1", inc. I). Não há dispositivo constitucional, nem tampouco norma legal que obrigue os proprietários a restaurar por sua conta os desmatamentos havidos, não raro efetuados por proprietários anteriores, sendo inegável a constituição de fato juridico perfeito e direito adquirido de não fazer".

Um terceiro aspecto merece consideração preambular, ou seja, que nas políticas impositivas de preservação ambiental, não pode o Estado violar o princípio da razoabilidade. Não pode impor ônus que represente a inviabilização de empreendimentos ou de exploração dos bens relacionados.

Nada mais irrazoável do que pretender "assegurar" exploração de $1 / 5$ de uma propriedade, atribuindo ao seu titular o ônus de manter reservas florestais ou de vegetação ambiente nos outros $4 / 5$, e obrigando-o a concorrer em condições desfavoráveis em mercado altamente competitivo. em que o preço de seus produtos é semelhante ao praticado pelos produtores que podem explorar em até $100 \%$ suas 
propriedades, não sujeitas às mencionadas restrições. Em outras palavras, não pode o legislador impor restrições à exploração agropecuária, sem ferir o princípio da livre concorrência. Proprietários rurais não podem concorrer em igualdade de condições com outros produtores que podem explorar até $5 / 5$ de sua propriedade sem necessidade de manter as restrições de $80 \%$ inexploráveis. Quem deve produzir em apenas $1 / 5$ de sua propriedade, com onus de manter $4 / 5$ intocáveis, perde competitividade perante os outros, que podem explorar a quase totalidade de sua área.

Em termos diversos, não pode o Poder Público - sem ferir seriamente o princípio da livre iniciativa e livre concorrência - impor que proprietários de áreas de exploração agropecuária, só as explorem em $20 \%$ impedindo-os de concorrer com outros que podem cultivar em até $100 \%$ de suas terras!"

Não se pode considerar razoável que - sem indenização - alguns proprietários sejam "imolados" a bem das presentes e futuras gerações, tendo inviabilizada a exploração de suas propriedades em $80 \%$, com perda da sua capacidade de concorrer no mercado, dada a redução da possibilidade de exploração econômica de seu imóvel a apenas $20 \%$ de sua extensão territorial, ou seja, de somente $1 / 5$ de suas terras.

É o que dispõe o artigo 16 da M.P. n. 1956-50/2000 assim redigido:

"Art. I6 As florestas e outras formas de vegetaçäo nativa, ressalvadas as situadas en área de preservação permanente, assim como aquelas não sujeitas ao regime de utilização limitada ou objeto de legislação especificica, são suscetíveis de supressão, desde que sejam mantidas, a título de reserva legal, no minimo:

I - oitenta por cento, na propriedade mural situada e'm área de floresta localizada na Amazônia Legal;

II - trinta e cinco por cento, na propriedade nural situada em área de cerrado localizada na Amazônia Legal. sendo no mínimo vinte por cento na propriedade e quinze por cento na forma de compensaçäo em outra área, desde que esteja localizada na mesma microbacia. e seja averbada nos termos do $\$ 72$ deste artigo;

III - vinte por cento, na propriedade rural situada em área de floresta ou outras formas de vegetação nativa localizada nas demais regiōes do país; e $I V$ - vinte por cento, na propriedade rural èn área de campos gerais localizada em qualquer regiäo do pais".

y Celso Bastos comenta o artigo 170, inciso IV. da C.F. como se segue: "A livre concorrência é indispensável para o funcionamento do sistema capitalista. Ela consiste essencialmente na existência de diversos produtores ou prestadores de serviços. É pela livre concorrência que se melhoram as condições de competitividade das empresus, forçando-its a um constante aprimoramento dos seus métodos tecnológicos, à diminuição dos seus custos, enfim, na procura constante da criação de condiçōes mais favoráveis ao consumidor. Traduz-se portanto numa das vigas mestras do êxito da economia de mercado. O contrário da livre concorrência significa o monopólio e o oligopólio, ambos situações privilegiadoras do produtur, incompativeis com o regime de livere concorrência" (Comentários à Constituiçūo do Brasil. $7^{\circ}$ volume. 2" ed., Ed. Salraiva, 2000, p. 27). 
Tal irrazoabilidade foi perfeitamente detectada pelo maior ecologista do Brasil e um dos maiores do mundo, responsável pela implantação das primeiras Estaçōes Ecológicas nacionais, Paulo Nogueira Neto que critica, por esse motivo, toda a legislação pertinente ao Código Florestal de 1965, com palavras duras, no que diz respeito à preservação de área agropecuária.

Declara sobre a "reserva legal" de $20 \%$ que:

"Na prática, no Brasil Sudeste. no Brasil Sul e em outras regiōes, isso significa que em inúmeras, propriedades rurais os seus donos terão de acabar com uma parte das suas atividades agricolas, para plantar florestas, em lugares onde hoje praticam agricultura de boa tecnologia. No meu entender, isso vai contra um dos princípios básicos do movimento ambientalista, de que é fundamental o fato de a erradicação da miséria sèr absolutamente necessária, não somente como imperativo moral, mas também para haver no mundo uma razónel qualidade de vida e uma situação demográfica melhor. Se tivermos de diminuir a agricultura praticada nas nossas melhores terras, a consequäencia lógica será menor produção de alimentos, menor enprego de mão-de-obra e maior pressão para a derrubada de florestas nas fronteiras agrícolas existentes na Amazônia. No momento em que ainda temos grandes bolsões de miséria no entorno das nossas grandes cidades, diminuir o cultivo e, portanto, encarecer assim o custo dos alimentos significa agir contra o meio ambiente. Repito que erradicar a miséria deve ser a nossa preocupação ambiental número um, por causa dos seus graves efeitos destrutivos, morais e materiais" (grifos meus) ${ }^{10}$.

Considera que a verdadeira preservação do meio ambiente dar-se-ia em substituindo tais reservas aleatórias, "legalmente" mal definidas e distribuídas, por projetos de exploração real da terra, de forma racional. Dizia:

"O movimento ambientalista tem recebido amplo apoio da opinião pública brasileira e mundial. Essa é a sua grande força política. Seria um grave erro perder esse apoio precioso, se agirmos de modo frontalmente contrário aos princípios do desenvolvimento auto-sustentável. Emperrar ou diminuir a produtividade de milhöes de propriedades rurais significa perder a simpatia e o apoio de que dispomos nas áreas agrícolas do Brasil.

Deixo aqui o meu apelo para que a situação seja resolvida com calma, bom senso e fidelidade aos princípios ambiéntalistas básicos, como é o caso da erradicação da miséria. Sem essa erradicação, será dificílimo solucionar o problema demográfico" (grifos meus)"

10 Net Estado, Espaço Aberto/As florestas e o Imposto Territorial Rural. Paulo Nogueira Neto, 8.6.1998.

11 Net Estado, Espaço Aberto/As florestas e o Imposto Territorial Rural, Paulo Nogueira Neto, 8.6.1998. 
Um outro aspecto merece reflexão, ou seja, o que diz respeito à violação do princípio da igualdade.

Resta, nos textos consultados, ferido também o princípio da igualdade.

Sobre não ser correto que deva ser atribuída "responsabilidade onerosa" a algum membro da coletividade - e desoneração para o Poder Público - é de se lembrar que a seleção de alguns cidadãos como responsáveis pela preservação de "áreas ambientais", denominadas de "reserva legal", tisna o princípio da igualdade. Com efeito, é manifestamente injurídico que, não o Poder Público e nem a comunidade como um todo, mas apenas alguns cidadãos sejam eleitos para arcar com a responsabilidade onerosíssima de preservar o meio- ambiente para a atual e as futuras gerações!!! Seriam "imolados" involuntariamente, no altar do "bem comum", como na época da "era do terror" de Robespierre, os sacerdotes eram imolados no santuário da deusa "Razão". Por que não a coletividade (a Constituição não impõe tal ônus a ninguém individualmente)? Por que não o Poder Público? Por que somente alguns "escolhidos" pela lei? Onde resta o princípio da igualdade, também formulado como um dos cinco princípios fundamentais e relevantes dos direitos e garantias individuais (art. $5^{\circ}$ "caput")?

Miguel Reale chega a considerar que tal onerosidade representia autêntica "contribuição de intervenção no domínio econômico". com o que restaria ferido um princípio da isonomia ampliado, qual seja, o da equivalência ${ }^{12}$. Sobre a matéria escrevi:

12 "As ocorrências referidas pela Consulente são de tal ordem que e não se pode falar, em todos os casos, em desapropriação indireta, - poder-se-ia afirmar que se pretende criar, pelas autoridades administrativas mencionadas, uma forma anômala e ilegal de contribuição social em prol do meio ambiente, não para recolhimento em dinheiro aos cofres públicos, mas sim indiretamente em material e serviços custeados pelos proprietários rurais.

Não há dúvida que a Conş̧ituição, em seu Art. 149, confere competência privativa à União para instituir "contribuições sociais", mas para os dois fins a que faz expressa referência. Ademais, como a contribuição social é uma "espécie tributária" (*), ela só poderá ser estabelccida mediante lei complementar que previamente a defina (Art. 149 da Carta Magna, em conexão como Art. 146 , III, "a"),

A " reserva legal" em apreço paira, em suma, tal como foi sumariamente enunciada, no reino da pura abstração, sendo de difícil configuração jurídica, extrapolando, a olhos vistos, o plano das restrições constitucionais ao direito de propriedade em razão de sua função social.

Não podemos, em verdade, olvidar, que, se devemos preservar os valores ecológicos, é também certo que, conforme art. $1^{\circ}$ da Carta Maior, lembrado no início deste Parecer, a livre iniciativa, essencial à produção e ao uso produtivo da propriedade, é um dos fundamentos do Estado Democrático de Direito.

Donde se conclui que a suposta imposição aos proprietários rurais da obrigação de reflorestar por conta própria, só é fruto de lastimável ignorância do Direito pátrio.

$\left(^{*}\right)$ Nesse sentido, vide RUY BARBOSA NOGUEIRA, Direito Financeiro, 1971, p. 142 e segs.; ALIOMAR BALEEIRO - Uma introduçāo à Ciência das Finanças, 2a. ed., 1958, vol. II, p. 453, e IVES GANDRA MARTINS - Teoria da Imposição Tributária. 2a. ed., 1998, p. 120)" (cópia de parecer em mãos do pareceristi). 
"Equivalente é um vocábulo de densidade ôntica mais abrangente do que "igual". A igualdade exige absoluta consonância em todas as partes, o que não é da estrutura do princípio da equivalência. Situaçōes iguais na eqüi. polência, mas diferentes na forma, não podem ser tratadas diversamente. A equivalência estende à similitude de situações a necessidade de tratamento igual pela política impositiva, afastando a tese de que os desiguais devem ser tratados, necessariamente, de forma desigual. Os desiguais, em situação de aproximação, devem ser tratados, pelo princípio da equivalência. de forma igual em matéria tributária, visto que a igualdade absoluta, na equivalência não existe, mas apenas a igualdade na equiparação de elementos (peso, valor etc.). Qual foi a razão para tal elasticidade ofertada pelo constituinte, para proteçũo dos contribuintes, vedando ao Poder Tributante adoção de técnica diversa?

A tradição brasileira de pouco respeito aos direitos dos cidadãos em matéria tributária - o Presidente Collor acaba de pedir ao Congresso a redução dos direitos dos contribuintes para fazer uma reforma tributária, que tem na essência o princípio de "maiores tributos, menores direitos" - certamente levou o constituinte a amarrar os poderes tributantes (três sobre o mesmo "pagador de tributos") aos grilhões seguros do princípio da igualdade, evitando simultaneamente: a) que, a título de tratamento desigual dos desiguais, se multiplicassem as hipóteses de situações diversas para neutralização do princípio da igualdade; b) servisse a redução legislativa do princípio da igualdade como forma de tratamento aplicável às perseguições fiscais em relação a setores, que estivessem em conflito com os governos. Entendo ter sido esta a razão fundamental que levou o constituinte, em relação ao princípio da igualdade, seja em seu aspecto subjetivo, seja naquele objetivo, a proteger todos os contribuintes contra o tratamento desigual, exigindo que este tratamento deva ser igual não apenas para situaçōes iguais, mas para situações equiparadas, equivalentes, com núcleo comum de identidade. Compreende-se assim porque o discurso do inc. Il é concluído com a afirmação de que a situação equivalente será detectada independentemente da denominação jurídica dos rendimentos, títulos ou direitos dos contribuintes.

Em outras palavras, quaisquer que sejam os contribuintes, quaisquer que sejam os fatos imponíveis, o tratamento isonômico se impõe, vedada qualquer forma de atuação discriminatória" ${ }^{13}$.

No que concerne à obrigação onerosa criada para aumentar o percentual de reflorestamento ou reconstituição de áreas que a lei anterior permitia restarem nesta situação, há também inequívoca maculação dos princípios da "irretroatividade" e da "não confiscatoriedade", que não se restringe apenas às questões tributárias".

13 Caderno de Pesquisas Tributárias $n^{\circ}$ 17, Co-edição CEU/Resenhá Tributária, 1992, p. 19/21.

$14 \mathrm{Na}$ referida ADIN 2010-2-DF hospedou a tese da proibição do efeito confisco da tributação, 
A questão referente à necessidade de replantio de áreas em que, pela legislação anterior, sua detenção não implicava tal responsabilidade, assim como das áreas que já estavam desmatadas. introduz imposição arbitrária, confíscatória e sujeita a indenização.

Na ADIN 2010-2-DF. o Ministro Carlos Mário Velloso encampa, em nível de efeito confiscatório, essa tese, ao dizer:

"Ademais, o efeito de confisco se caracterisaria, sobretade, no fato, por exemplo, de o servidor, em razão da exigência fiscal, ter que se privar de bens ou utilidades de que vinha se utilizando"15 (grifos meus).

O desconforto da medida é cle tal ordem, que seus próprios defensores institucionais - que alegavam haver princípio de ordem pública a justificar as modificações legislativas — foram obrigados a reconhecer a injustiça, criando fórmula não constante da lei, para minorar o efeito de onerosidade confiscatória imposta:

"Neste casos, a celebraçäo do TAC rivia impedir grave injustiça de criar, por vezes, irreparáveis prejuiasos a quem rinha agindo fielmente em conformidade com as determinaçóes legais; enquanto ao mesmo tempo a Administração retifica seus atos administrativos (altorizaçōes de desmate) à nova realidade para exigir do interessado, assim que findo o prazo do $T A C$, o camprimento das obrigações ali dispostas.

É o parecer, s.m.j.

PAULA DARIN SOUZA (Procuradora Federal/PROGE/IBAMA).

LIA CHAGAS DORNELLES (OAB 15,656 - PROGE/IBAMA)" (grifos meus $)^{16}$.

A questão não é saber se haveria ou não princípio de ordem pública, na visão do governo, a prevalecer sobre o direito assegurado anteriormente, mas sim de se saber se há princípio de ordem pública oponível a princípios que constituem cláusulas

determinado trecho do voto do Min. Carlos Mário Velloxo: "É que a Constituição naio totera a utilização de tributo com efeito de confisco (C.F. art. 150, IV). Como se chegal a essal conclusĩo? Qual seria o conceito de "tributo com efeito de confisco"?" O conceito é indeterminado, caso em que o juiz laborará em área que chamaríanos de "área cinzenta". Em primeiro lugarr, a questão, ao que me parece. deve ser examinada no conjunto de tributos gue o servidor pagará. no seu contracheque. dado que se trata de tributo incidente sobre o vencimento. salário ou provento. Este é, também. o entendimento de lves Gandra da Silva Martins ("Comentários à Constituiçấo do Brasil". Saraiva, vol. IV,p. 161 e seguintes), como lembrado pelo Sr. Ministro Relator" (Pesquisals Tributárias Novat Série 6. Dircitos Fundamentais do Contribuinte. Co-ed. CEU/Ed. Revista dos Tribunais, 2000. p. 52/3).

15 Pesquisals Tributárias Nova Série 6. Direitos Fundamentais do Contribuinte, Co-ed. CEU/Ed Revista dos Tribunais, 2000, p. 53.

16 Parecer PROGE N. 904/02, Proc. n 4979/01-PA, do Instituto Brasileiro de Mcio-Ambiente e dos Recursos Naturais Renováveis. Procuradoria Geral. 
pétreas da Constituição. É de se saber se poderia prevalecer a instituição de "ônus inexistente" na Constituição para determinados cidadãos. Em outras palavras, não é saber se o princípio de ordem pública deve ser aplicado na preservaşáo ambiental. mas sim saber se há principio público que transfira responsabilidade que a Constituição impõe ao Poder Público, para o cidadão, de forma onerosa.

À evidência, a resposta é negativa. A injustiça detectada pelos eminentes pareceristas não se resolve pela aplicação de "inaplicável princípio de ordem pública", mas pela adoção do princípio constitucional da "não onerosidade" de preservação ambiental para "escolhidos cidadãos ao sacrifício", assim como pelo principio da irretroatividade de norma, que pretende retirur direitos constitucionais assegurados e impor obrigaçôes inconstitucionais, inexistentes no t'mpo pretérito.

O princípio da irretroatividade, neste caso. é aplicável sob o duplo enfoque, qual seja, o do direito de exploração da propriedide agrícola nos moldes anteriores e o da inaplicabilidade de norma inconstitucional a grupo "selecionado de sacrificados", a bem das geraçäes presentes e futuras e do próprio Governo" ${ }^{17}$.

Parece-me, pois, de manifesta inconstitucionalidade o dispositivo constante do artigo 16 da M.P. n. 1956-50/2000.

São Paulo, 17 de Dezembro de 2003.

17 Pinto Ferreira escreve: "A norma constitucional refere-se à regra de super-direito ou sobredireito, que o direito alemão chama Uberrecht. O super-direito tem por tinalidade editar regras com o objetivo de solucionar us conflitos de leis no tempo. A constituiçĩo norte-aınericana de 1787 (art. I, seção 9, $n^{\circ} 3$ ) proibiu a lei "ex pust facto" o que significa al vedação do seu efeito retro-operante.

A lei não retroage, no direito brasileiro, para ofender o direito adquirido, o ato juridico perféto e a coisa julgada.

Black no seu dicionário de Direito usa as expressões leis expost (facto, leis retrospectivas laws) lei retroativa (retroactive law) como sinônimus.

Lei retroativa é a lei que olha o patssado e procura afetar e atingir fatos já ocorridos. atingindo destarte direitos adquiridos denominados "vested rights" no direito norte-americano.

A irretroatividade é um princípio de direito pelo qual a lei nova não pode retroagir os seus efeitos ao passado com relação ao direito adquirido, a coisa julgalda e aos atos jurídicos perfeitos.

Ribas ensinava que "a não-retroatividade das leis não consiste na sua absoluta inaplicabilidade aos casos pretéritos, ou processos pendentes, e sim. antes do respeito aos direitos adquiridos". (grifos meus) Com isto busca-se a certeza de relaçāo jurídica e a garantia de segurança dada ao cidadão" (Comentários à Constituiçäo Brasileira, $1^{\circ}$ vol. Ed. Saraiva, 1989, p. 143) 


\section{O Autoritarismo e a Ordem Constitucional no Brasil}

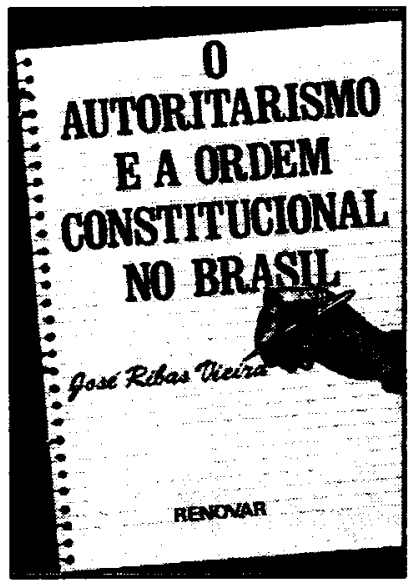

Esta obra assume a postura de falência de um Estado de Direito. A permanente restrição das garantias de direitos individuais e da inexistência de mecanismos de proteção contra os abusos do poder de Estado no país estimulou o autor a utilizar categorias de Estado de exceção (Marx/Poulantzas) e hegemonia (Gramsci) para interpretar a experiência constitucional brasileira. Este livro serve de instrumento prático de formaçāo e conscientização dos estudiosos do Direito, representando em contraponto as obras tradicionais publicadas no campo da Teoria Geral do Estado/Direito Político no país.

Ref. 0011

Form. 14x21

Brochura

1988

108 págs.

\section{Obras Completas de Orlando Bitar Estudos de Direito Constitucional e Direito do Trabalho}

Por sua profundidade erudita e por seu alcance crítico no campo da filosofia jurídica e do direito constitucional moderno, Orlando Bitar é um dos mais abalizados e ilustres publicistas deste país. Logo às primeiras páginas deste admirável trabalho - A Lei Fundamental de Bonn e o Sistema Parlamentar da República Federal Alemā - o leitor pressente encontrar-se diante de um espírito percuciente e inquisitivo, que estudou com porfiada aplicação o que de melhor se produziu na Alemanha.

Ref. 0107 2 volumes
Encadernado Form. 16x23
1.202 págs. 1996

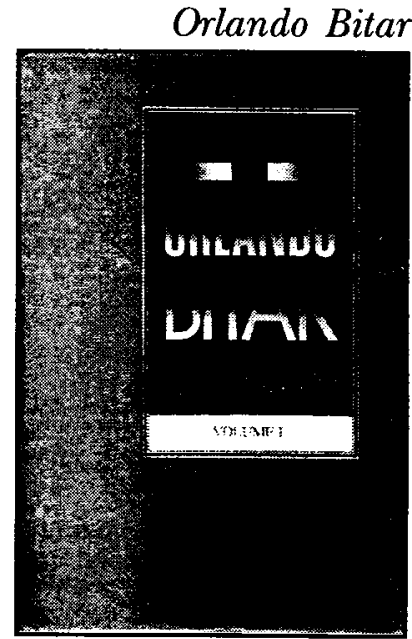

